\title{
A protocol for extraction and purification of high- quality and quantity bacterial DNA applicable for genome sequencing: a modified version of the Marmur procedure.
}

\section{Francisco Salvà-Serra ( $\sim$ francisco.salva.serra@gu.se )}

Culture Collection University of Gothenburg (CCUG), Sahlgrenska Academy, University of Gothenburg, Gothenburg, Sweden; Microbiology, Department of Biology, University of the Balearic Islands, Palma de Mallorca, Spain

Margarita Gomila ( $\square$ marga.gomila@uib.es)

Microbiology, Department of Biology, University of the Balearic Islands, Palma de Mallorca, Spain Liselott Svensson-Stadler

Culture Collection University of Gothenburg (CCUG), Sahlgrenska Academy, University of Gothenburg, Gothenburg, Sweden

\section{Antonio Busquets}

Microbiology, Department of Biology, University of the Balearic Islands, Palma de Mallorca, Spain

\section{Daniel Jaén-Luchoro}

Culture Collection University of Gothenburg (CCUG), Sahlgrenska Academy, University of Gothenburg, Gothenburg, Sweden

\section{Roger Karlsson}

Culture Collection University of Gothenburg (CCUG), Sahlgrenska Academy, University of Gothenburg, Gothenburg, Sweden

\section{Edward R. B. Moore}

Culture Collection University of Gothenburg (CCUG), Sahlgrenska Academy, University of Gothenburg, Gothenburg, Sweden

\section{Method Article}

Keywords: genomic DNA, extraction, genomics, bacteria, next-generation sequencing, whole-genome sequencing, DNA-DNA hybridization; Marmur procedure.

Posted Date: August 9th, 2018

DOI: https://doi.org/10.1038/protex.2018.084 
License: (c) (i) This work is licensed under a Creative Commons Attribution 4.0 International License. Read Full License 


\section{Abstract}

Here we present a modified version of the Marmur procedure $\backslash($ Marmur, 1961) for extraction, isolation and purification of bacterial DNA. The protocol is effective in providing large amounts of high quality and high molecular weight genomic DNA from Gram-negative and Gram-positive bacteria, suitable for numerous downstream applications, including next-generation sequencing.

\section{Introduction}

Nucleic acids are the basis of the biology of every organism. Numerous methodologies have been developed to extract, study and analyse DNA, as it contains information providing insights into the lifestyles and intrinsic characteristics of any organism. In the field of microbiology, DNA has been used for decades as material for studying microorganisms at the highest level of genetic resolution, i.e., at the nucleotide level. For instance, genomic DNA-DNA similarity continues to be a genotypic "gold standard" methodology for confirming whether two bacterial strains belong to the same species. Additionally, the development of next-generation sequencing technologies has enabled the rapid and cost-effective determinations of entire genome sequences of microorganisms, revolutionizing microbiological research. However, the sequencing technologies require that the DNA is extracted in a form that meets particular quantity and quality requirements. In this protocol, we present a modified version of the Marmur procedure $\backslash($ Marmur, 1961), a robust and straightforward method for successful extraction, isolation and purification of total DNA from most Gram-negative and Gram-positive bacteria. The protocol provides large amounts of high-quality DNA, sufficient and suitable for most downstream applications, including DNA-DNA hybridization, DNA fragment profiling, as well as for the most widely-used next-generation sequencing technologies, i.e., Illumina \(Illumina, Inc.), Ion Torrent $\backslash($ Thermo Fisher Scientific, Inc.), PacBio $\backslash$ (Pacific Biosciences of California, Inc.) and MinION \(Oxford Nanopore Technologies). Bacterial DNA, using this extraction protocol, has been offered as a service at the Culture Collection University of Gothenburg $\backslash(\mathrm{CCUG})$ during the last 10 years.

\section{Reagents}

- EDTA-Saline $\backslash[\mathrm{C} 10 \mathrm{H} 16 \mathrm{~N} 2080.01 \mathrm{M}$ and NaCl $0.15 \mathrm{M} ; \mathrm{pH}=8.0 \times 800 \mu \mathrm{ll}] \cdot \cdot$ Lysozyme $\backslash[300 \mathrm{mg} / \mathrm{ml} \times 10$ $\mu \mathrm{l}]$. Mutanolysin $\backslash[1,000 \mathrm{U} / \mathrm{ml} \times 10 \mu \mathrm{l}]$. RNase A, DNase-free $\backslash[100 \mathrm{mg} / \mathrm{ml}$ x $7.0 \mu \mathrm{l}]$. SDS $\backslash$ (Sodium Dodecyl Sulfate) $\backslash[\mathrm{NaC1} 2 \mathrm{H} 25 \mathrm{SO} 425 \% \backslash(\mathrm{w} / \mathrm{v}) \times 80 \mu \mathrm{l}]$. Sodium chloride $\backslash[\mathrm{NaCl} 5 \mathrm{M} \times 250 \mu \mathrm{l}]$ • Chloroform:isoamyl alcohol $\backslash[\mathrm{CHCl} 3: \mathrm{C} 5 \mathrm{H} 12 \mathrm{O} \backslash(24: 1) \times 2.0 \mathrm{ml}]$. Sodium acetate $\backslash[\mathrm{C} 2 \mathrm{H} 9 \mathrm{NaO} 53 \mathrm{M} \times 90$ $\mu \mathrm{l}]$. A Absolute isopropanol \[C3H80 x $600 \mu \mathrm{l}]$. 'Low'-TE \[Tris \(C4H11NO3) $1 \mathrm{mM}$ and EDTA \ $(\mathrm{C} 10 \mathrm{H} 16 \mathrm{~N} 2 \mathrm{O} 8) 0.1 \mathrm{mM} ; \mathrm{pH}=7.0-8.0 \times 100 \mu \mathrm{ll}$.

\section{Equipment}

- Sterile $1.5 \mathrm{ml}$ microcentrifuge tubes. - Sterile $2.0 \mathrm{ml}$ microcentrifuge tubes. • Vortex. $\cdot$ Heating block or water bath. $\cdot$ Microcentrifuge. $\cdot$ Orbital shaker. $\cdot$ Glass rods. 


\section{Procedure}

1. Suspend a fully-loaded inoculating loop of bacterial biomass in a $2.0 \mathrm{ml}$ tube with $800 \mu \mathrm{l}$ of EDTASaline; vortex at maximum speed to mix thoroughly. 2. Add $10 \mu \mathrm{l}$ of lysozyme. 3. If Gram-positive bacteria, add $10 \mu \mathrm{l}$ of mutanolysin. 4 . Mix by vortexing for a few seconds to suspend the biomass. 5 . Add $7 \mu \mathrm{l}$ of RNase A. 6 . Incubate at $37^{\circ} \mathrm{C}$ for at least $15-45 \mathrm{~min}$; vortex every $15 \mathrm{~min}$. 7. Add $80 \mu \mathrm{l}$ of SDS. 8 . Vortex at maximum speed for a few seconds; the viscosity is increased. 9. Incubate at $65^{\circ} \mathrm{C}$ for $10 \mathrm{~min}$; vortex once during this time. 10 . Spin down briefly and add $250 \mu \mathrm{l}$ of sodium chloride $5 \mathrm{M}$. 11 . Vortex at maximum speed for a few seconds and spin down briefly. 12. Add $400 \mu \mathrm{l}$ of chloroform:isoamyl alcohol. 13. Vortex at maximum speed for a few seconds; shake for $15 \mathrm{~min}$ at 1,400 rpm on an orbital shaker. 14 . Centrifuge at $>13,000 \mathrm{xg}$ for $15 \mathrm{~min}$. 15. Transfer the top-layer to a new tube $\backslash(2 \mathrm{ml})$; avoid the protein layer. 16. Add $400 \mu$ of chloroform:isoamyl alcohol again; shake vigorously by hand and centrifuge again. 17. Repeat step 16 until there is no protein layer. 18. To $1 \mathrm{ml}$ of solution, add $90 \mu \mathrm{l}$ of sodium acetate $3 \mathrm{M}$. 19. To $1 \mathrm{ml}$ of solution, add $600 \mu \mathrm{l}$ of cold isopropanol $\backslash\left(4^{\circ} \mathrm{C}\right)$. 20. Precipitate the DNA by inverting the tube several times by hand, when threads of DNA are seen, shake the tube harder to clump the DNA threads. 21. Spool the DNA using a glass rod and leave it to dry completely, for at least $5 \mathrm{~min}$ at room temperature. 22. Alternatively, for steps $20-21$, if there is no formation of threads, spin down at > $13,000 \times \mathrm{g}$ for $10 \mathrm{~min}$, carefully discard the supernatant and let the DNA pellet dry completely at room temperature. 23. Suspend the spooled or pelleted DNA in $100 \mu$ of 'low'-TE. 24. Incubate the resuspended DNA over-night at $4^{\circ} \mathrm{C}$ for complete resuspension.

\section{Timing}

The entire protocol takes approximately four - five hours.

\section{Troubleshooting}

Low amounts of DNA might be obtained for some taxa of bacteria that are highly-resistant to enzymatic and detergent lysis $\backslash$ (e.g., Mycobacterium spp.). Therefore, in some cases mechanical lysis $\backslash$ (e.g., bead beating) might be necessary.

\section{Anticipated Results}

The quantity and quality of the extracted and purified DNA will vary depending on the amount of starting material and the nature of each particular bacterium. In most cases, when eluted in $100 \mu$ l of 'low'-TE, concentrations $\backslash$ (Qubit BR measurement) of several hundreds of nanograms per microliter $\backslash$ (i.e., tens of micrograms in total) and absorbance ratios of $1.8-2.0 \backslash(260 / 280 \mathrm{~nm})$ and $2.0-2.2 \backslash(260 / 230 \mathrm{~nm})$ can be expected to be recovered. DNA fragments larger than $60 \mathrm{~kb}$ can also be expected for most bacteria. Once dissolved in 'low'-TE, the DNA is ready to be used for most downstream applications $\backslash$ (e.g., Oxford Nanopore sequencing). However, further purification protocols may be applied in cases where downstream applications are very sensitive to contaminants and impurities $\backslash$ (e.g., PacBio sequencing). 
But, this modified protocol provides a standard, relatively simple protocol for obtaining the DNA for most cases of whole-genome sequence determinations.

\section{References}

Marmur, J. \(1961). A procedure for the isolation of deoxyribonucleic acid from micro-organisms. Journal of Molecular Biology 3\(2), 208-IN201. doi: https://doi.org/10.1016/S0022-2836\(61)80047-8.

\section{Acknowledgements}

This work was supported by the Department of Clinical Microbiology, Sahlgrenska University Hospital, Gothenburg, Sweden. 